\title{
Franz Rosenzweig and Karl Barth: A Chapter in the Jewish Reception of Dialectical Theology*
}

\author{
Daniel Herskowitz / University of Oxford
}

The aim of this article is to gain a better understanding of the way in which Jews understood and reacted to dialectical theology, already in the 1920s and 1930s in Weimar Germany, by approaching the instance of the frequent conjunction of Franz Rosenzweig with Karl Barth. ${ }^{1}$ By examining the manner in which Rosenzweig was understood and situated vis-à-vis Barth in the immediate period after the publication of their respective notable works, Der Stern der Erlösung and Der Römerbrief, this article demonstrates that Jewish thinkers participated in, and responded to, the major theological dispute of the time, namely, the dispute over the promises and perils of the so-called dialectical or crisis theology.

$$
* * *
$$

The appearance of Karl Barth's explication of Paul's Epistle to the Romans was an event of great significance in the theological landscape of Weimar Germany. ${ }^{2}$ Breaking from the neo-Kantian and liberal doctrines in which he was reared, in this work Barth attacked the liberal tendency to situate the divine in the realm of history, subjectivity, and the ethical. Formulating his thought through strict oppositions, Barth stressed the fundamental con-

\footnotetext{
* I would like to thank Ido Ben-Harush for his valuable comments on an earlier draft of this article.

${ }^{1}$ As such, sections of this article can be read as a yet-untold chapter in the Rezeptionsgeschichte of Rosenzweig's thought as well. Two excellent studies on Rosenzweig's reception do not discuss Karl Barth. See Thomas Meyer, Zwischen Philosophie und Gesetz: Jüdische Philosophie und Theologie Von 1933 bis 1938 (Leiden: Brill, 2009), 166-212. Peter E. Gordon makes only a brief mention of Barth in his "Rosenzweig Redux: The Reception of German-Jewish Thought," Jewish Social Studies 8, no. 1 (Fall 2001): 1-57, esp. 27.

${ }^{2}$ Karl Barth, The Epistle to the Romans, 2nd ed., trans. Edwyn C. Hoskyns (London: Oxford University Press, 1968), xiii; hereafter cited as Romans. First edition published in December 1918; second edition in 1922.
}

(C) 2017 by The University of Chicago. All rights reserved.

0022-4189/2017/9701-0004\$10.00 


\section{The Journal of Religion}

flict between the temporal and the eternal, the immanent and the transcendent, the sinful and the holy, the divine and the worldly. God, in this account, is utterly transcendent, inscrutable, and contradictory to all human faculties and fields of cultural endeavors. Barth's famous statement best illustrates the core of his theology: "If I have a 'system' then it consists in the fact that I keep what Kierkegaard has called the 'infinite qualitative difference' between time and eternity consistently in mind. God is in heaven and you on earth." ${ }^{3}$ Not only is humanity cast in a world bereft of God, Barth taught, but God is the negation of the world. In the thundering tone characteristic of this period in his writing, Barth proclaims that our overall ignorance of God perfectly reflects our own condition: "the only thing we are certain of, that which we can demonstrate, is always only the negation, the negativity of the human." ${ }^{4}$ Alongside the view of Deus absconditus, Barth offered an account of revelation as a vertical, factum brutum eruption from beyond, disrupting the fallen human existence. Outside of revelation, we know nothing of God. It can be said that Barth's entire theology at the time pivots on the insight that "at the beginning of all knowledge of God stands not human self-acknowledgement but God's own knowing, man's being known by God, that is, revelation."

Matching its penchant for binaries, the responses to the Römerbrief were as fierce as they were divided. His theology, with its uncompromising attitude toward divine transcendence and aseity, directly responded to the spiritual needs of the time and stirred much enthusiasm. Reflecting the postwar disillusioned with the liberal, humanistic, historicist spirit that animated the nineteenth-century theological and intellectual climate, Barth's depiction of a world completely fallen away from God gave voice to the ubiquitous sense of despair and overall deterioration that gripped many. Together with a group of theologians such as Emil Brunner, Rudolf Bultmann, Friedrich Gogarten, and Eduard Thurneysen, a theological movement was established, which had a huge impact on the theologically inclined younger generation in Germany. ${ }^{6}$

Conversely, the radicalism of Barth's view was met by a rising chorus of detractors who perceived it as too one-sided; the decisive disjunction between God and creation was taken to be immensely problematic from a Christian point of view. Indeed, many resisted what they found to be the

\footnotetext{
${ }^{3}$ In the preface to the second edition of Romans, xiii. On the crucial impact of Kierkegaard on Barth in these early years, see Thomas F. Torrance, Karl Barth: An Introduction to His Early Theology, 1910-1931 (London: SCM Press, 1962), 44-47. In the intellectual climate of the first decades of the twentieth century, the examination of the Jewish reception of Barth covers some common ground with the Jewish reception of Kierkegaard and of Martin Heidegger.

${ }^{4}$ Karl Barth, "The Word of God and the Task of Theology," in The Word of God and Theology, trans. Amy Marga (London: Bloomsbury, 2011), 178-79.

${ }^{5}$ Karl Barth, The Theology of the Reformed Confessions, trans. and annotated by Darrell L. Guder and Judith J. Guder (Louisville, KY: Westminster John Knox Press, 2005), 65.

${ }^{6}$ Gary Dorrien, The Barthian Revolt in Modern Theology (Louisville, KY: Westminster John Knox Press, 2000), 36-37.
} 
close semblance between Barth's theological scheme and Marcion's heretical Das Evangelium vom fremden Gott. ${ }^{7}$ This charge, hardly uncommon at the time, was voiced most notably by Adolf von Harnack, who protested that Barth's Marcionism was negated to the Christian message. "You condemn all Christian pedagogy," Harnack accused, "and sever, like Marcion, every link between faith and the human. In my view you have the example of Jesus against you." ${ }^{8}$ Barth came under attack also by some of the preeminent theologians and New Testament scholars of the day-Protestant and Catholic alike-who spotted marks of Gnosticism and Marcionism already in the first edition of the Römerbrief, and even more so in the second edition. ${ }^{9}$ While Barth would admit the comparison was warranted, he would nevertheless conclude, with much justification, that "at the crucial points these agreements break down." ${ }^{10}$ And yet eventually, also many of his theological allies, such as Paul Tillich, Helmut Thielicke, Emil Brunner, Rudolph Bultmann, and even Dietrich Bonhoeffer, found in his framework an almost impossible emphasis on negativity. Although profoundly divergent, these theologians, each in his own way and for his specific purposes, expressed the view that for all Barth's talk of paradoxes and dialectics, his program was actually a one-sided dialectic of exaggerated transcendence that was not only detrimental to theology but also ultimately alien to the Christian message.

\footnotetext{
${ }^{7}$ Benjamin Lazier, God Interrupted: Heresy and the European Imagination Between the World Wars (Princeton, NJ: Princeton University Press, 2012), esp. 21-36.

${ }^{8}$ H. Martin Rumscheidt, Revelation and Theology: An Analysis of the Barth-Harnack Correspondence of 1923 (Cambridge: Cambridge University Press 1972), 37. Harnack was himself a driving force in the resurgence of Marcionism, albeit understood differently, in that period. See Adolf von Harnack, Marcion: Das Evangelium vom fremden Gott (Leipzig: J. C. Hinrichs'sche Buchhandlung, 1921). On this, see Lazier, God Interrupted, 27-36.

9 Adolf Jülicher, "Ein moderner Paulusausleger," Die Christliche Welt 34 (1920): 466-68. In English: "A Modern Interpreter of Paul," in The Beginnings of Dialectical Theology, trans. Keith R. Crim, ed. James M. Robinson (Richmond, VA: John Knox Press, 1968), 72-81; Karl L. Schmidt, "Marcion und wir: Die Gegenwartsbedeutung von Harnacks Marcion," Kartell Zeitung: Organ des Eisenacher Kartells akademisch-theologischer Verein 31 (1920/1921): 83-85; Erich Przywara, Das Geheimnis Kierkegaards (Munich: Oldenbourg, 1929), 30; Wilhelm Loew, "Noch einmal Barths Römerbrief," Die Christliche Welt 34 (1920): 585-87; Hans Windisch, "Rezension: Barth, Karl: Der Römerbrief," Theologische Literaturzeitung 45 (1920): 200-201; Erich Foerster, "Marcionitisches Christentum," Die christliche Welt 35, 45 (1921): 811; Arnold Hein, "Moderner Marcionitismus und praktische Theologie," Theologische Blätter 32, nos. 6-7 (1922): 148. On these responses, see Richard E. Brunett, Karl Barth's Theological Exegesis: The Hermeneutical Principals of the Römerbrief Period (Tübingen: Mohr Siebeck, 2001), 14-23. At the time, the term "Gnosticism" was applied to a variety of theological positions which underscored the radical rift between the fallen world and human existence in it, and the transcendent divine God. The framing of the opposition between the God of Christianity and the God of the Old Testament articulated by Marcion of Sinope along similar lines made the term "Gnosticism" often interchangeable with the term "Marcionism" in those years. This identification as well as the overly extensive application of the blanket-term "Gnosticism" has been widely contested ever since. See, e.g., Michael A. William, Rethinking “Gnosticism”: An Argument for Dismantling a Dubious Category (Princeton, NJ: Princeton University Press, 1996).

${ }^{10}$ Barth, Romans, 13; see also 241-42; and Rumscheidt, Revelation and Theology, 50, 95-100.
} 
Around the same time Barth wrote the first edition of his Romans, Franz Rosenzweig experienced the writing spree that would give birth to his masterpiece, The Star of Redemption. Yet it is more than this chronological fact that led recent studies to note the kinship of intellectual horizon and theological agenda between both thinkers. Considering that Rosenzweig's thinking emerged out of a critical response to the historicism and compromise of God's transcendence that marked the theological efforts of nineteenthcentury liberal theology, Amos Funkenstein noted that "Rosenzweig's later theological position was . . a analogous to Karl Barth's." ${ }^{11}$ Randi Rashkover, in her expansive book-length comparative study of the two men, regards Barth to be Rosenzweig's "most methodologically similar contemporary." 12 David Myers contextualizes Rosenzweig's antihistoricism and primacy of revelation with the surging Weimarian Kulturpessimissmus that was the backdrop of Barth's theology of crisis, as well as with the Offenbarungsglaube of Rosenzweig's converted friend Eugen Rosenstock and cousins Hans and Rudolph Ehrenberg, which influenced him greatly (and predated Barth's Romans by a few years). ${ }^{13}$ Evidence for this can be found in Rosenzweig's early 1914 essay "Atheistische Theologie," where he expressed dismay for the pervasive tendency to "avoid the idea of revelation." 14 In the letter to Rudolph Eherenberg from November 18, 1917, that has come to be known as the Urzelle of the Star, Rosenzweig declares revelation as his "long sought-after philosophical Archimedean point." ${ }^{15}$ The centrality of revelation is manifested in the Star as well, both structurally-it is discussed in the second book, the heart of the Star - and thematically. Rosenzweig begins his explo-

${ }^{11}$ Amos Funkenstein, Perceptions of Jewish History (Berkeley, CA: University of California Press, 1993), 297. On Rosenzweig's attitude toward historicism, see David N. Myers, Resisting History: Historicism and its Discontents in German-Jewish Thought (Princeton, NJ: Princeton University Press, 2003), 68-105; Stephen T. Katz, "On Historicism and Eternity: Reflections on the 100th Birthday of Franz Rosenzweig," in Der Philosoph Franz Rosenzweig (1886-1929) Internationaler Kongreß Kassel 1986, Band II, ed. Wolfdietrich Schmied-Kowarzik (Munich: Verlag Karl Alber, 1988), 745-69; Paul Mendes-Flohr, "Franz Rosenzweig and the Crisis of Historicism," in The Philosophy of Franz Rosenzweig, ed. Paul Mendes-Flohr (Hanover: University Press of New England, 1988), 138-61; for a different view, see Leora Batnitzky, "On the Truth of History or the History of Truth: Rethinking Rosenzweig via Strauss," Jewish Studies Quarterly 7, no. 3 (2000): 223-51.

${ }^{12}$ Randi Rashkover, Revelation and Theopolitics: Barth, Rosenzweig, and the Politics of Praise (New York: T\&T Clark International, 2005), 3. It should be noted that unlike the aforementioned studies as well as our own, the purview of Rashkover's study extends beyond the early period of Barth's Romans.

${ }^{13}$ Myers, Resisting History, 94-100.

${ }^{14}$ Franz Rosenzweig, "Atheistische Theologie," in Zweistromland: Kleiner Schriften zu Glauben und Denken, ed. Reinhold Mayer and Annemarie Mayer, Franz Rosenzweig: Der Mensch und sein Werk, vol. 3 (Dordrecht: Martinus Nijhoff, 1984), 697 (henceforth FRMW). In English: Franz Rosenzweig, Philosophical and Theological Writings, trans. and ed. Paul Franks and Michael L. Morgan (Indianapolis: Hackett, 2000), 24.

${ }^{15}$ Franz Rosenzweig, "The Cell of The Star of Redemption," in Franz's Rosenzweig's "The New Thinking”, ed. and trans. Alan Udoff and Barbara E. Galli (Syracuse, NY: Syracuse University Press, 1999), 45. 
rations with three irreducible and categorically distinct elements: God, World, and Man. In this initial state, God is completely distinct from Man and World, and Man lives solipsistically in an immanent realm completely bereft of God. This radical gulf between God and Man is breached, in Rosenzweig's narration, by the shattering event of revelation. ${ }^{16}$ These recent studies, to be sure, did not settle for simply pointing at affinities. As Myers argues, it would be "facile to insist on total harmony between him and his Protestant contemporaries." 17 Michael Morgan and Paul Franks note that in some of his writings Rosenzweig "has in mind recent developments in Christian theology and especially the emergence of Barth and radical theology," but his reaction is that of "a genuine worry with Barth and his disciples." ${ }^{\prime 18}$ And similarly, Samuel Moyn sketches their shared intellectual background and itinerary but also stresses Rosenzweig's critical response to Barth. $^{19}$

Yet the juxtaposition and comparison of Barth and Rosenzweig did not surface only in recent scholarship. As we shall see, the juxtaposition and comparison were made already in the 1920s and 1930s in Germany. Indeed, it is of great significance that the association between the two thinkers was first made by Rosenzweig himself.

$$
* * *
$$

"For many years I was a Barthian myself," Rosenzweig wrote to Martin Buber in 1923, "but almost ten years ago Rosenstock surgically extracted my Barthianism from me." ${ }^{20}$ The following year, in July 16, 1924, he refers to this early position in a similar fashion, describing to Buber "the entire field of views in which I then lived," before the momentous Umkehr of his life, as

\footnotetext{
${ }^{16}$ Compare also Robert Gibbs, Correlations in Rosenzweig and Levinas (Princeton, NJ: Princeton University Press, 1992), 97; Mark Lilla, The Stillborn God: Religion, Politics, and the Modern West (New York: Knopf, 2007), 258-95. Rosenzweig and Barth were linked also through their ties to the Patmos group, together with Eugen Rosenstock-Heussy, Leo Weismantel, Werner Picht, and Hans Ehrenberg, and the editors of the journal Die Kreatur. See below, and also Udoff and Galli, “The New Thinking," 178; Barbara Ellen Galli, Franz Rosenzweig and Judah Halevi: Translating, Translation and Translators (Montreal: McGill-Queen's University Press, 1995), 3023.

${ }^{17}$ Myers, Resisting History, 97.

${ }_{18}^{18}$ Rosenzweig, Philosophical and Theological Writings, 88.

${ }^{19}$ Samuel Moyn, Origins of the Other: Emmanuel Levinas between Revelation and Ethics (Ithaca, NY: Cornell University Press, 2006), 113-63. Moyn's reading of Rosenzweig seeks to problematize what he sees as Peter E. Gordon's overstated comparison between Rosenzweig and Heidegger, permitted by downplaying the centrality of revelation in Rosenzweig's system. See Peter E. Gordon, Rosenzweig and Heidegger: Between Judaism and German Philosophy (Berkeley: University of California Press, 2003); Samuel Moyn, "Is Revelation in the World?," Lewish Ouarterlv Review 96, no. 3 (Summer 2006): 393-403. On Barth and Rosenzweig, see also Eberhard Busch, Barth-ein Porträt in Dialogen: Von Luther bis Benedikt XVI (Zurich: Theologischer, 2015), 151-69.

${ }^{20}$ Franz Rosenzweig, letter to Buber, February 14, 1923, in Briefe und Tagebücher II, ed. Rachel Rosenzweig and Edith Rosenzweig-Scheinmann, in collaboration with Bernhard Casper, FRMW, vol. 1 (The Hague: Martinus Nijhoff, 1979), 892-94.
} 


\section{The Journal of Religion}

"a kind of Barthianism." ${ }^{21}$ Obviously, for Rosenzweig to be a Barthian per se ten years prior to 1923 is impossible. In 1913 Barth was still bound to the clutches of liberal theology, and the book that would make him a theological referent was yet to be written. But as Benjamin Pollock has helpfully shown, by "my Barthianism" Rosenzweig is most likely denoting his early Marcionist standpoint. Describing his stance from around 1910 up until July 7, 1913, Rosenzweig states that "at the time I was on the best road to Marcionitism [Marcionitismus]." ${ }^{22}$ In this early stage of his intellectual biography, Rosenzweig held a dualistic worldview that denied the moral and spiritual status of creation and posited an alien God accessible through revelation alone. Redemption, according to this Gnostic position, consists above all in the redemption from the world. The noted event in which Rosenstock "surgically extracted" these glaring views is the Leipziger Nachtgespräch, the momentous event of "conversion" that eventually led Rosenzweig toward Judaism and, effectively, to the philosophical system unfolded in the Star. It is this memorable nightly conversation that brought Rosenzweig to break with his Gnostic outlook and to conclude that "God created the world and [is] not just the God of revelation." 23 Thus what can be learned from Rosenzweig's statements to Buber is that from his perspective, any purported kinship with Karl Barth pertains to the philosophical convictions that he surely held, but which ultimately had to be overcome for the Star to become possible. Indeed, referring to the Star, Rosenzweig would claim that "so little could I have written it before 1913 when I myself was still a Marcionist." ${ }^{24}$ Importantly, by dubbing his early views "Barthianism," Rosenzweig exposes something of the way he perceived Barth's theological program: as a form of Marcionism.

As Pollock illustrates, the Star is precisely a rejoinder to the Marcionist worldview. In his words, "the Star elaborates what may be best understood ... as the most compelling metaphysical alternative to Gnostic dualism, a metaphysical doctrine that responds to the same concerns expressed in Gnosticism, but which resolves such concerns through dialectical development rather than static opposition." ${ }^{25}$ According to this reading, the first section of the Star manifests an overall Gnostic position-the three basic elements are presented as utterly distinct and isolated. This state of separation is ulti-

\footnotetext{
${ }^{21}$ The Letters of Martin Buber: A Life of Dialogue, ed. Nahum N. Glatzer and Paul Mendes-Flohr, trans. Richard and Clara Winston and Harry Zohn (New York: Schocken, 1991), 319.

${ }^{22}$ Franz Rosenzweig, "Paralipomena," in Zweistromland, 99; unless otherwise noted, all translations are my own. On this see Benjamin Pollock, "On the Best Road to Marcionism: Franz Rosenzweig's Early Theology," Iewish Ouarterly Review 102, no. 2 (2012): 224-55, incorporated into his Franz Rosenzweig's Conversions: World Denial and World Redemption (Bloomington: Indiana University Press, 2014).

${ }^{23}$ Rosenzweig, "Paralipomena," 99.

${ }^{24}$ Franz Rosenzweig, letter to Margrit (Gritli) Rosenstock-Huessy, February 20, 1921, see Eugen Rosenstock-Heussy Fund website, http://www.erhfund.org/online-article/gritli-letters-gritli -briefe-1921/\#feb.

${ }^{25}$ Pollock, Rosenzweig's Conversions, 11.
} 
mately shattered, and the remainder of the book is dedicated to the articulation of the relations between God and World through creation, between God and Man through revelation, and between Man and World through redemption. The break from the Gnostic vision in the Star is exemplified not only through highlighting the relational notions of creation, revelation, and redemption but also by the fact that these relational moments themselves are interlinked. The eruptive, miraculous event of revelation has a decisive impact on the World by unveiling its true nature as creation. In turn revelation is disclosed as grounded and proleptically already present in creation. While originating from a chartless distance, in some way, revelation already belongs in the world, in creation, by way of prophetic promise. Similarly, the redemptive future is anticipated in revelation. Redemption is not achieved therefore by overcoming or transcending the world but rather by human effort in the world, toward its fulfillment and the fulfillment of the other nodes of Man and, above all, of God. Ultimately the geometrical shape of the star of David - the star of redemption - is construed by a reconciliation and selffulfillment of the separated coordinates of God, World, and Man, linked together by creation, revelation, and redemption, themselves interconnected. The Star then holds a confutation to Rosenzweig's initial Gnostic opposition between God and the World. The All, in Rosenzweig's vocabulary, is not torn by an unsurmountable dualism but is rather a plurality developing toward a definitive unity.

Furthermore, in contrast to Marcion's demand of Christianity to forfeit all ties with the Old Testament and its zealous deity, Rosenzweig extends an anti-Marcionist position according to which Judaism and Christianity have a shared mission in the economy of redemption. Their complementing roles are illustrated by the image of the star-Judaism is its burning fire, Christianity its ranging rays. ${ }^{26}$ Thus, just as the identification of the God of creation with the God of revelation responds to the Gnostic position that differentiates between the two, so the purported roles ascribed to the Jews and Christians reflect a response to the demand to cut the ties between the two. Judaism needs Christianity to successfully spread the message of God to the world and guard it from its tendencies toward detachment, and Christianity, with its double parentage of Judaism and paganism, inherently runs the risk of falling back into Marcionism, and hence needs Jews to uphold its monotheistic proclamation. "It was always the hidden enemies of Christianity, from the Gnostics to the present day, who wanted to deprive it of its 'Old Testament," Rosenzweig asserts. ${ }^{27}$ "And as that ever-present struggle of the Gnostic shows, it is the Old Testament, which enables Christianity to with-

\footnotetext{
${ }^{26}$ Franz Rosenzweig, The Star of Redemption, trans. William W. Hallo (Boston: Beacon, 1972), 415. Interestingly, Rosenzweig cites Romans 11:25 to support his claim for the Christian necessity of the Jews' existence.

${ }^{27}$ Rosenzweig, Star, 414.
} 


\section{The Journal of Religion}

stand its own danger." ${ }^{28}$ Thus the overcoming of Gnosticism is a dynamic reflected in the different stages recorded in the Star.

It should not, however, be understood from this interpretation that the Star is to be read as a theological rejoinder to Barth's exegetical work on Romans. As stated, the compositions of the Star and the first edition of Romans were almost parallel, and the second edition was published three years after Rosenzweig's magnum opus. Yet it is clear that the Star possesses a response to and an overcoming of the Marcionist outlook that Rosenzweig will shortly identify with Barth's theology. Moreover, as we shall now see, in the following years, and to a large degree throughout the 1920s as a whole, Rosenzweig directly confronted Barth's radical theological positions, most often by drawing on his earlier formulations in the Star.

$* * *$

In a 1922 letter, Rosenzweig confides to Buber that as he commenced with the project of translating ninety-five poems of the great medieval thinker and poet Jehuda Halevei, he began to read the second edition of Barth's Romans "with admiration for the ability to make so much out of pure negation." ${ }^{29}$ Rosenzweig, of course, was not unfamiliar with negation. His methodology in the first section of the Star consists of the reduction of each element of God, Man, and World to its infinitesimal nothingness. But this move is followed by a careful reconstruction of the elements through affirming the not-nothing and negating the nothing of the being of each element. Adding to this remark to Buber, Rosenzweig raises the question as to whether Barth "still in fact acknowledges Christ and revelation in the first place?," since "his God, whose only role is to constantly deny itself, must still recognize and protect also against this danger." Rosenzweig questions the commensurability of Deus absconditus and Deus revelatus in such a radically negative theological project. "If Barth is conscious of what he is doing at this point," Rosenzweig determines, "he should arrive at a more versatile concept of God," one that is able to uphold some form of affirmation or positivity. ${ }^{30}$ Rosenzweig, like many of Barth's Christian retractors and colleagues, found Barth's conception of God all too one-dimensional and exclusively negative.

But alongside this limited conception of God, Rosenzweig also found its schematization somewhat dissatisfactory. In a fascinating comment, Rosenzweig compares Kierkegaard with the dialectical theologians and inquires, "why is there such a different feel in Kierkegaard than in Barth and Gogarten?" 31 It is, he suggests,

${ }^{28}$ Ibid., 415; translation slightly amended.

${ }^{29}$ Franz Rosenzweig, letter to Buber, in Briefe und Tagebücher II, 875-76.

${ }^{30}$ Ibid.

${ }^{31}$ By pairing Barth and Gogarten together, as he often does, Rosenzweig overlooks the important differences between the two theologians. This tendency is somewhat common in the contemporary Jewish responses to Dialectical Theology. 
surely not merely because he is the original and they are the copies, because there are so brilliant copies, that it is indeed worth to look at them in themselves. But behind every paradox of Kierkegaard one feels the biographical Absurda, and therefore one must believe him. While behind the Barthian colossal negations one feels nothing other than the wall on which they are painted, and this wall is whitewasheda very immaculate and well-ordered life. And therefore this painting is credible [glaubhaft] to me only as a painting. Not incredible [unglaubhaft], you understand. But still just a casual credibility [Glaubenhaftigkeit]. This thinking is not transparent, everything is already in it, and therefore, nothing more behind it. ${ }^{32}$

Rosenzweig recognizes Barth's and Gogarten's debt to Kierkegaard but nevertheless emphasizes that the personal existential anguish expressed by Kierkegaard grants his "infinite qualitative difference" the genuineness that is required to see it as it is - a truly incredible position of faith. Barth's "colossal negation," on the other hand, appears to be the result of a logical deduction or the requirements of dogma, but lacks the tormented livedexperience of absurdum that this doctrine implicates, and is therefore merely credible.

A more elaborated confrontation with the Barthian position is presented in the illuminating comments Rosenzweig added to his translation of Halevi's poem יה אנה אמצאך (God, where shall I find You?), which he rendered, significantly, Der Fern-Und-Nahe. As his comments disclose, Rosenzweig situates this hymn in the context of the current theological controversy over the Marcionist tradition of which he takes Barth to be a representative. Introducing what he considers its central theme, Rosenzweig explains that this hymn "is animated by one particular thought, but it is the last thought that human thinking can grasp, and the first that Jewish thinking grasps: that the faraway God is none other than the near God, the unknown God none other than the revealed one, the Creator none other than the Redeemer. . . This thought has been repeatedly discovered anew in the sphere of revelation; and inside and outside that sphere has been forgotten over and over throughout the centuries, from Paul and Marcion to Harnack and Barth. Always discovered anew, always forgotten anew." ${ }^{33}$ This statement draws on the position Rosenzweig reached in the wake of the Leipziger Nachtgespräch and that is explicated in much complexity in the Star-that "God created the world and [is] not just the God of revelation," as the misconception of the Gnostic dualism between the near and remote God posits. But it is especially worth noticing that Rosenzweig defines the conception of a Fern-Und-Nahe God as "Jewish thinking." This "Jewish" theological understanding is con-

\footnotetext{
${ }^{32}$ Franz Rosenzweig, letter to Buber, in Briefe und Tagebücher II, 876. See also Hans Liebeschütz, Von Georg Simmel zu Franz Rosenzweig: Studien zum Jüdischen Denken im deutschen Kulturbereich (Tübingen: Mohr Siebeck, 1970), 171 n. 80.

${ }^{33}$ Franz Rosenzweig, "Jehuda Halevi: Fünfundneunzig Hymnen und Gedichte Deutsch und Hebräisch,” in Sprachdenken im Übersetzen, ed. Rafael N. Rosenzweig, FRMW, vol. 4 (The Hague: Martinus Nijhoff, 1983), 68-71. In English, Galli, Franz Rosenzweig and Judah Halevi, 204.
} 


\section{The Journal of Religion}

trasted, and culled as a reply, to Barth's dualism. By drawing a distinction between human thinking and Jewish thinking, Rosenzweig frames Barthianism, the current torchbearer of the Marcion tradition, as still far from reaching the fulfillment of human thought - which Jewish thinking holds from the outset: the unity of the God of creation and the God of redemption, of the transcendent and the immanent. Echoing the view in the Star regarding the universal "Judaizing" of the world in redemption, Rosenzweig insinuates here that the last human thought will, eventually, be the "Jewish" thought of the unison of God.

The problem with the tradition culminating in Barth, Rosenzweig continues, is that it is guilty of making the very mistake it accuses all other theologies to have made, namely, the error of determining God's attributes from our own limited knowledge. "We theologians cannot help but make prescriptions for God's conduct out of our knowledge," Rosenzweig argues. "We know that God can be known only in His presence, and at once we make out of this a law of Him: that He does not permit Himself to be known in His absence." However, by articulating this law, we inadvertently but nevertheless intrinsically accede to the pretense of regulating what can or cannot be said of God. "In truth, however, Rosenzweig asserts, "we could easily leave it to Him as to when and how and what of Himself He wants to be known." This rebuke is directed against Barth's dogmatism, which seems to force God into its negative formulations. As mentioned above, Rosenzweig's 1914 "Atheistic Theology" is an indictment of the theological trends that highlighted the historical and the ethical only to neglect what he called "the offensive idea of revelation." However, in these remarks on Halevi's poem from a decade later, Rosenzweig targets what can be seen as the opposite state of theological reflection - the state in which the offensiveness of the idea of revelation is borne out to its extreme and granted exclusive theological import. "After a long drought," Rosenzweig describes the current state of theology, "today we have a theology, mostly Protestant, that leaves nothing to be desired as to accuracy. We have it now: that God is wholly other; that to talk about him is to talk him away, that all we can tell is what his effect is on us." Rosenzweig illustrates what in his view is a distorted conditionthe "result of this monstrous accuracy"-through a figurative image: "we accurate people today all stand together like children in a circle. One person asserts one accurate point: his neighbor scorns him with an even more accurate statement that this utterance was false because it was accurate. And so it goes around the circle until we arrive back at the first: the whole thing is called theology." 35 The result of this ominous situation is that the efforts of theology consist in negation and denial, but little more.

\footnotetext{
${ }^{34}$ Quoted in Galli, Franz Rosenzweig and Judah Halevi, 205.

35 Ibid., 205. In a letter to Rabbi Max Dienemann from November 7, 1924, he explains that when he speaks of neo-Protestants he has Barth "personally before [his] eyes" (Briefe und Tagebücher II, 998-99).
} 
In his commentary on another poem by Halevi, which is part of the Yom Kippur liturgy, entitled ימינך נשא עוני and translated as Heimkehr, "Homecoming," Rosenzweig alludes to dialectical theology when he asks with respect to repentance: "Does God or does the human being take the first step? That is a real question, not, as Protestant theologians today would like to believe, a preliminary question already solved." 36 The core of the matter lies, for Rosenzweig, in the fact that on the one hand, the Barthian position, according to which the first step is taken by God, is clearly true: "the human always senses his own lack of power whenever he stands before God, and thus necessarily must await and request the first step from God." And yet on the other hand-and here Rosenzweig clearly distances himself from Barth-"at the same time he hears that which he cannot help but hear: that God demands the first step from him, from the human." 37 This deliberation demonstrates that for Rosenzweig, the dialectical relation between the human and God surfaces from God but yet it is not a unilateral one; the human has an essential role, her activity is necessary. This is best manifested, for Rosenzweig, in the conversation between the sinner seeking forgiveness and God, "an unending conversation" that reaches a high point in Yom Kippur in the final liturgical moment of Ne'ilah where reconciliation-homecoming-is fulfilled. "At this moment he is as near to God, as close to his throne as human beings can be," Rosenzweig muses. ${ }^{38}$ In a letter to Buber from February 14, 1923, Rosenzweig expresses his reservations with Barth's conception of God by putting to use Jewish liturgy recited over Yom Kippur, noting that "Barth and Gogarten sing the litany of the refrain מלך עליון, 'the Highest King', throughout the entire year." 39 The Barthian God is always only the Highest King, but never a close God.

Rosenzweig's clear discontent with Barth's theology notwithstanding, it is important to notice that he does not protest against Barth's view regarding the radical transcendence of God. Indeed, he explicitly says "I do not deny the doctrine of difference [Unterscheidungslehre]" between God and the world. ${ }^{40}$ Yet Rosenzweig identifies in Barth a unilateral dialectic prioritizing remoteness over proximity which he himself is unwilling to concede. In contrast, he promotes a bilateral dialectic wherein nearness is an essential part of the dialectic; the human-divine relationship is marked by both conjunction and disjunction. ${ }^{41}$ Describing the conversation between man and God in his comments on "Homecoming," Rosenzweig emphasizes that in it the

\footnotetext{
${ }^{36}$ Galli, Franz Rosenzweig and Judah Halevi, 194.

${ }^{37}$ Ibid., 195.

${ }^{38}$ Ibid., 196-97.

${ }^{39}$ Rosenzweig, letter to Buber, February 14, 1923, in Briefe und Tagebücher II, 892-94.

${ }^{40}$ Franz Rosenzweig, letter to Dienemann, in Briefe und Tagebücher II, 998-99.

${ }^{41}$ Compare Jacques Derrida, "Interpretations at War: Kant, the Jew, the German," in Acts of Religion, ed. Gil Anidjar (New York: Routledge, 2002), 143; Elliot R. Wolfson, Giving Beyond the Gift: Apophasis and Overcoming Theomania (New York: Fordham University Press 2014), 34-36.
} 


\section{The Journal of Religion}

ultimate distinction between the divine and the human is not beclouded: "the conversation between the two voices continues in that unending distance with which it began." ${ }^{42}$ And yet despite upholding this distance, Judaism also teaches relationship and contact: "When at other times God's ways are distant from human ways, the way of Israel's God and the way of his people meet at the eternally flaming Sinai. Even today, on this day [of Yom Kippur], when the Jew is wholly human, and his God is wholly Judge of the world, this bridge does not disappear from consciousness." ${ }^{\text {43 }}$ For Rosenzweig, as for Barth, the stark rift between God and human is the point of departure for theological reflection; yet unlike Barth, for Rosenzweig it is not also the end point. What Rosenzweig stated in the Star with regards to the difference between negative theology and his own thinking nicely captures his contention with the Barthian perspective. Negative theology takes "the path [that] leads from an existing Aught [Etwas] to Nought [Nichts]"; however, "we do not take this path, but rather the opposite one from Nought to Aught. Our goal is not a negative concept but, on the contrary, a highly positive one." ${ }^{44}$ Divine transcendence and the unknowability of God is, indeed, firmly embraced by Rosenzweig, yet it is not taken to be the alpha and omega of the human relation to God. "Of God we know nothing," he declares in the Star. "But this not-knowing is a not-knowing of God. As such it is the beginning of our knowledge of him. The beginning, not the end." ${ }^{45}$ Moreover, as made clear in the aforementioned expositions of Halevi's hymns, the doctrine of divine transcendence does not invalidate the possibility of divine immanence. In Moyn's astute formulation, the difference between Barth and Rosenzweig is that "for Rosenzweig, in the starkest contrast to Barth, transcendence and immanence were not mutually exclusive but mutually necessary." "46

This point is reemphasized by Rosenzweig in an essay titled "Der Ewige: Mendelssohn und der Gottesname" from July 1929, only a few months before his untimely death. Here Rosenzweig protests against Mendelssohn's decision to translate the Tetragrammaton as "the eternal" (Der Ewige). Betraying the mark of eighteenth-century rational theology, Mendelssohn attempts to convey something of the philosophical essence of God, of "God's necessary existence" or unity. But this scholastic-like concern is alien to the biblical world, Rosenzweig insists. For the people of the Bible, not divine eternity but divine presence and encounter was of primal concern. He thus distinguishes, following Halevi once again, between the pagan god, the "God of Aristotle," and the Jewish God of the Bible, "the God of Abraham."

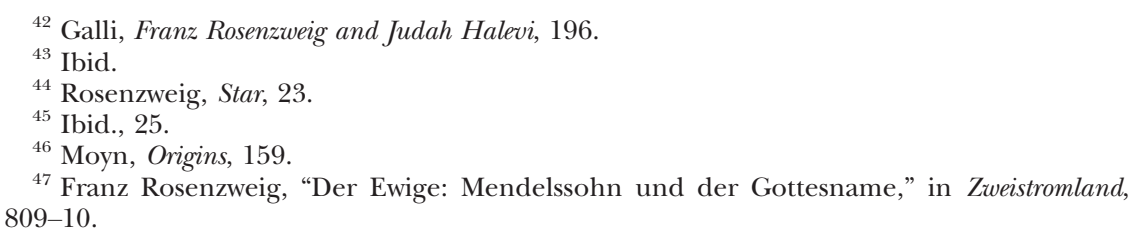


In Rosenzweig's understanding, "biblical 'monotheism' does not consist in knowledge of the unity of the divine Being," as is the case with paganism, although to be sure, this "ordinary" conception is presupposed. Rather, it "knows this God in its unity with what is most personally and immediately experienceable." 48 The key term for understanding Rosenzweig's perception of the biblical God is "equation" (Ineinssetzung). In his view, as already expressed in his comments on Halevi, the Jewish proclamation is the "Jewish equation of the far [fernen] with the near [nahen], the 'whole' [ganzen] with the "particular' [eigenen]." ${ }^{49}$ It is worth noting that the translation of this essay into English renders Ineinssetzung as "fusion," which is not incorrect, although it allows a certain ambiguity regarding what is most essential in Rosenzweig's proposal. ${ }^{50} \mathrm{~A}$ unity of fusion can be understood either as the merging of two distinct elements resulting in their disintegration into a third element combining the two, or as the unity of what Rosenzweig in the Star called the relation of "and," which denotes the unison of two distinct elements into a single unity without compromising the identity of each element. The "and" of God and World, for instance, attaches the two elements, but God remains God, and World remains World. It is a unity with difference-which constitutes one of the critical insights of Rosenzweig's New Thinking. But neither of these understandings match what is proclaimed in the present article as the unity of the biblical God. Here the duality does not disappear through mutual incorporation, nor is it maintained intact side by side. Here the manifestation of duality is in truth identity. Hence rendering Ineinssetzung as "equation" seeks to avoid confusion and to stress the unity within God. It should be stressed, nevertheless, that here too Rosenzweig does not deny the radical transcendence of the divine. Rather, he announces that understanding the actual unity of the transcendent and immanent in God is "the essence of Judaism." 51

But not only of Judaism. In continuation with the position presented in the third section of the Star, Rosenzweig contends that the actual unity of God is "through the Trinitarian dogma, however much broken and in danger of relapse in the pre- and non-Jewish division, also the Christian essence." 52 The danger referred to here is that Christianity will deny itself its Jewish origin and relapse back into paganism; in other words, the threat of Marcionism. As a matter of fact, Rosenzweig judges that this danger is more imminent and palpable than it perhaps seems - it is indeed presently prevailing through the teachings of dialectical theology: "the seriousness and actuality of this danger is shown again in the present [in] Barth and

48 Ibid.

49 Ibid.

${ }^{50}$ Franz Rosenzweig, “The Eternal': Mendelssohn and the Name of God,” in Martin Buber and Franz Rosenzweig, Scripture and Translation, trans. Lawrence Rosenwald and Everett Fox (Bloomington: Indiana University Press, 1994), 99-113.

${ }^{51}$ Rosenzweig, Der Ewige, 810.

52 Ibid. 


\section{The Journal of Religion}

Gogarten."53 Once again, Rosenzweig's identification of Barth with Marcionism is confirmed. And in accordance with the position in the Star, Barthianism is precisely the result of the Christian jettisoning of its Jewish heritage, which is revealed to be, most critically for Rosenzweig, the equation of the remote and near God. As Rosenzweig explicates, "this equation is the kern of biblical revelation and that which makes it the Jewish bible." ${ }^{" 54}$ The underscoring of rupture and discontinuity that lies in the core of Barth's radical theology ultimately gives way to the tendency toward relation and unison that marks Rosenzweig's New Thinking.

In addition to situating dialectical theology within the Star's scheme of the trinal relationship between paganism, Judaism, and Christianity - and identifying it with the former - what Rosenzweig also implies here is that despite Barth's claim to return to scripture as the ultimate compass for a faithful biblical theology, his erroneous presuppositions deny him of identifying the heart of the revealed biblical teaching. This view was equivalently conveyed in Rosenzweig's aforementioned comments on Halevi's hymn Der Fern-Und-Nahe, where he insinuates that Barth's desire to overcome the modern idolatrous shortcomings and return to a pristine biblical moment of the revealed Word of God remains unfulfilled. That God is "wholly other" is not, in Rosenzweig's eyes, only an empty statement with respect to God, but also an utterly modern statement. .55 "The possibility of the proof of God", he extends, "is the simple result of the fact that God, as you will never tire of repeating, is Wholly Other. No, not even a result. Rather this 'wholly-other' is itself the modern proof of God, namely the residue of the other proofs thinned out to the outermost distance of abstraction." 56 Thus not only is Barthianism completely at odds with Judaism, according to Rosenzweig, it also represents a distorted version of Christianity. This stance is again voiced in a letter to Gritli Rosenstick-Heussy, dated April 24, 1924, where Rosenzweig writes of "the damned Barth, who makes Christianity so inconvenient that its sheer inconvenience is finally the most comfortable thing in the world." 57

Alongside the translation of Jehuda Halevi's poems and essay writing, Rosenzweig's major literary project throughout most of the 1920s was the translation of the Bible with Martin Buber. And as Paul Mendes-Flohr has shown, their translation is rightly understood as partaking in a larger effort

\footnotetext{
${ }^{53}$ Ibid.

${ }^{54}$ Ibid.

${ }^{55}$ For the development of the notion of "wholly other," particularly in the context of Rosenzweig and Barth, see Moyn's Origins.

${ }^{56}$ Galli, Franz Rosenzweig and Judah Halevi, 206.

${ }^{57}$ See Eugen Rosenstock-Heussy Fund website, http://www.erhfund.org/online-article /gritli-letters-gritli-briefe-1924/\#apr.
} 
of combating the present-day Marcionist upsurge. ${ }^{58}$ Indeed, Rosenzweig himself perceived it so. Writing to Buber on July 29, 1925, he remarked that "it should be quite clear to you that the theoretical status to which the neoMarcionites strove is practically already here today. ... We are thus becoming missionaries." ${ }^{59}$ In this respect, their shared project of translation was, for Rosenzweig, an act of resistance against the neo-Marcionist desire to expunge the Hebrew Bible from German culture. It is perhaps not surprising then that the translation holds further evidence for Rosenzweig's identification of Barthianism with the Gnostic position of detachment of God from creation.

One such evidence is located, appropriately, in the translation of the first chapters of Genesis. It is generally common among biblical scholars to perceive the (roughly) first two chapters of Genesis as representing two differing, even competing, accounts of creation. Among other divergences, the first chapter depicts a distant, impersonal and nonrelational God (Elohim), while the second narrative portrays an active and personal God $(Y H W H)$ who enters into a relation with humans. Commenting on their translation of Genesis 2:4-7, the verses that are often considered the beginning of the second account of creation, Buber and Rosenzweig write: "this second narrative of the creation [Schöpfungsgeschichte] is indeed the exact opposite of the first, anti-creaturely, Barthian one." 60 The creation narrative of a detached God touching the world only asymptotically is perceived as "Barthian" and "anti-creaturely." ${ }^{61}$ What is revealed here is that despite Rosenzweig's concurrence with Barth with respect to divine transcendence, he is in discord with the Calvinist assumption at play in Barth, according to which the world is so fallen and sinful it is utterly inhospitable to accommodate the divine, so much so that between God and the world lay contradiction. For Rosenzweig, Barth's radical yet narrow conceptualization of divine transcendence engenders an inadmissible undermining of the status of the world as creation.

A further illustration of this perception is disclosed in a letter to Margarete Susman von Bendemann, dated January 27, 1929, where Rosenzweig explains that he and Buber tried to distance themselves from Luther's

\footnotetext{
${ }^{58}$ Paul Mendes-Flohr, "Martin Buber and the Metaphysics of Contempt," in Divided Passions: Jewish Intellectuals and the Experience of Modernity (Detroit: Wayne University State Press, 1991), 221.

${ }^{59}$ Franz Rosenzweig, letter to Buber, July 29, 1925, in Briefe und Tagebücher II, 1055-56.

${ }^{60}$ Franz Rosenzweig, "Aus Franz Rosenzweigs Arbeitspapieren zur Verdeutschung der Schrift," in Sprachdenken im Übersetzen, 12.

${ }^{61}$ Rosenzweig's statement, that what prevented him from buttressing his dualistic worldview was "the first sentence of the Bible" should be understood as a general attestation to his newly found faith in the world as creation and in God as creator, and not as a statement regarding specific conventions of biblical scholarship. See his letter to Rudolf Ehrenberg from October 31, 1913, in Briefe und Tagebücher I, ed. Rachel Rosenzweig and Edith RosenzweigScheinmann, in collaboration with Bernhard Casper, FRMW, vol. 1 (The Hague: Martinus Nijhoff, 1979), 133.
} 
translation of a certain "dark text" (dunklen Text], despite it being more faithful to the original verse, because it was "too Barthian-Gogartenian." The referred text is probably 2 Sam. 23:5, which is rendered by Luther as "Denn alles mein Heil und Tun ist, da $\beta$ nichts wächst!," thereby underscoring the nullity of human endeavors in the face of God. In Buber's and Rosenzweig's translation, by contrast, human agency and activity in the face of God is highlighted: "ja, all mein Freiheit, alle Lust, ja, ihm zu lasse ichs sprießen." ${ }^{62}$ This is one case in which the motivation behind a specific translation is revealed as deliberately resisting a "Barthian" interpretation. How many other verses were translated with the desire to overturn a "too BarthianGogartenian" interpretation will in all probability remain unknown. Yet what becomes apparent through this example is that Buber and Rosenzweig sought to combat the "anti-creaturely" forces of the day not only through the very undertaking of their translation, but through its textual details as well.

Upholding the status of creation pertains to a further point. We have seen that the retention of the stark dualisms that permeate Barth's scheme is deplorable in Rosenzweig's view. One such dualism is that between the utterly autonomous Word of God-and, by implication, the dogmatic project of articulating it - and all fields of human knowledge, from which it is categorically distinct. From Rosenzweig's perspective, this dichotomist position leads to unacceptable disciplinary — and existential — compartmentalization. One such abnormal separation is that between science and religion. "This separation, the penultimate slogan [Schrei] of protestant theology," Rosenzweig maintained in a short published letter on his attitude toward biblical scholarship, "is rooted in Kant—so much the worse for Kant [ um so schlimmer für Kant]! Barth and Gogarten are tuned in to it—and so much the worst for Barth and Gogarten [um so schlimmer für Barth und Gogarten]!"63 According to Rosenzweig, whose disposition toward unity is, as we have seen, undeniable, this separationist position is detrimental for both science and religion. The differentiation between them is indeed sound, yet inasmuch as the world is perceived as creation, drawing a decisive cleft between the two is baseless: "There is only one truth. ... The object of science is not God but the world. But God has created the world, and thus the object of science. God is transcendent but also transcendental with regards to science." ${ }^{64}$ In contrast to the divorcing of faith and reason achieved by dialectical theology, the correct schematization, Rosenweig contends, is gläubiges Wissen, faithful reason.

\footnotetext{
${ }^{62}$ Letter to Margarete Susman-von Bendemann, January 27, 1929, in Breife und Tagbücher II, 1207; “Aus Franz Rosenzweigs Arbeitspapieren zur Verdeutschung der Schrift," in Sprachdenken im Übersetzen, 230-32. Rosenzweig also mentions Barth in the context of the translation of the Bible in a letter to Joseph Carlebach, May 31, 1929, Breife und Tagbücher II, 1214-15.

${ }^{63}$ Franz Rosenzweig, "Die Einheit der Bibel: Eine Auseinandersetzung mit Orthodoxie und Liberalismus," in Kleinere Schriften (Berlin: Schocken, 1937), 131-32.

${ }^{64}$ Ibid., quoted in Nahum N. Glatzer, Franz Rosenzweig: His Life and Thought (New York: Schocken, 1953), 209-10.
} 
This view of conjoining secular sciences and faith, or philosophy and theology, was elaborated upon in the Star, where Rosenzweig observes that "it is the same man, disbelieving child of the world and believing child of God in one, who comes with dual pleas and must stand with dual thanks before Him who gives of his wisdom."65

Examining the manner in which Rosenzweig read Barth's theology vis-àvis his own thinking, it can be affirmed that the early conceptual affinity to which Rosenzweig admits eventually gave way in his mature thinking to a position that is not only removed from that of the Swiss theologian, but which self-consciously contested the palpable spiritual threat it saw Barthianism to be. Whether or not it constitutes a defensible reading, it is clear that Barth's reception by Rosenzweig is characterized by opposition, confrontation, and rejection. Certainly, by framing his own thinking in such a manner, Rosenzweig actively downplays the significant moments of affinities he shares with Barth's theology. And yet we must also bear in mind the stakes: in the sphere of theology, slight differences or disparate emphases may reflect or even lead to fundamental disagreements that sometimes separate piety from idolatry.

Parenthetically, it should be noted that there is little doubt that Barth would have rejected Rosenzweig's position as plainly idolatrous-some of Barth's closest theological comrades were condemned by him for far less. Yet a conclusive judgment in this respect cannot be made, for there is little to suggest any serious engagement with Rosenzweig's work on Barth's part. Recalling his early ties with the Patmos group, Barth claimed, tellingly, to have intentionally remained at arm's length from its members, for the group "wanted to overwhelm me and choke me with its Gnosticism." He also claims to have composed his Romans to defend himself against the phenomenon that the Patmos circle represented. ${ }^{66}$ In his mature years, he admitted, the intensity of his other studies prevented him from gaining more than a superficial familiarity with modern Jewish thinkers, Rosenzweig included: "Biblical Israel as such gave me so much to think about and to cope with," Barth reported to Dr. Friedrich-Wilhelm Marquardt, "that I simply did not have the time or intellectual strength to look more closely at Baeck, Buber, Rosenzweig, etc." ${ }^{67}$ This utterance reveals that Barth was aware of the "canonization" of Rosenzweig's thought as an essential moment in modern Jewish thought, but also

\footnotetext{
${ }^{65}$ Rosenzweig, Star, 297.

${ }^{66}$ Letter to Kornelis Heiko Miskotte, July 12, 1956, in Karl Barth-Kornelis Heiko Miskotte: Briefwechsel 1924-1968, ed. Hinrich Stoevesandt (Zurich: Theologischer, 1991), 81. Cited, without the latter point, in Eberhard Busch, Karl Barth: His Life from Letters and Autobiographical Texts, trans. John Bowden (Grand Rapids, MI: Eerdmans, 1994), 141. On Barth's links to the Patmos group, see Busch, Barth - ein Porträt in Dialogen, 158-66.

${ }^{67}$ Karl Barth, Letters 1961-1968, trans. and ed. Geoffrey W. Bromiley (Edinburgh: T. \& T. Clark 1981), 262. This is despite his friend Miskotte's insistence on the theological benefits of studying Rosenzweig. See: Eberhard Busch, Meine Zeit mit Karl Barth: Tagebuch 1965-1968 (Göttingen: Vandenhoeck \& Ruprecht, 2011), 435.
} 


\section{The Journal of Religion}

that this was apparently an insufficient reason to compel him to develop and enrich his otherwise limited familiarity with Rosenzweig's thinking.

The spiritual challenge presented by dialectical theology and Barth's thought in particular was accorded wide attention in Christian circles, but it intrigued Jewish intellectuals as well. ${ }^{68}$ Parallels can be drawn between at least part of the appeal of Barth and Rosenzweig to their respective confessional communities: both put forth a theological program as a critical reaction to the derided heritage of nineteenth-century liberal theology that came to be perceived by many as compromising divine otherness as well as curtailing the authentic expression of faith. Thus an insight into the ideational responses Barth's thought evoked from the Jewish interwar generation is discernible by the occasions in which he was placed in conjunction with Rosenzweig. Indeed, the early readers of the Star recognized the related issues addressed by both thinkers. For example, in an essay on liberal Judaism, the liberal rabbi Heinrich Lemle noted the significant religious consequences of the changing attitude toward history and existence, "as it appears in existential philosophy, in dialectical theology, through Rosenzweig." 69 Recalling his formative years in Weimar Germany, Leo Strauss credited their shared affirmation of the primacy of revelation for the revival of theology that occurred between the wars: "the reawakening of theology ... for me is marked by the names of Karl Barth and Franz Rosenzweig," he wrote. ${ }^{70}$

However it must be emphasized that the Jewish reception of Barth and dialectical theology in the interwar period is marked above all by a critical

\footnotetext{
${ }^{68}$ See Daniel Herskowitz, "An Impossible Possibility? Jewish Barthianism in Interwar Germany," Modern Theology (July 2017), forthcoming. In a scholarly recollection of the early 1930s, Alexander Altmann, who will be discussed below, speaks of the period as one in which "the liberal theology of the historical school culminating in Harnack's account of Christianity had left a spiritual void and called forth the 'theocentric theology' of Erich Schaeder, Tillich's doctrine of 'Kairos', and above all, Barth's and Gogarten's 'Dialectical theology'. Judaism too was affected by the crisis of Historicism." Alexander Altmann, "Theology in Twentieth-Century German Jewry," Leo Baeck Institute Yearbook 1, no. 1 (1956): 201.

${ }^{69}$ Heinrich Lemle, "Vernachlässigung aus Armut? Ein Wort zur Lage im religiösen Liberalismus," Der Morgen 11 (February 1937): 512.

${ }^{70}$ Leo Strauss, "A Giving of Accounts," in his Jewish Philosophy and the Crisis of Modernity: Essays and Lectures in Modern Jewish Thought, ed. Kenneth Hart Green (Albany: State University of New York Press, 1997), 460. In a 1940 lecture, Strauss pairs the two again when he juxtaposes Karl Barth and "a remarkable philosophic writer of predominantly theological interest [who] was fond of the fact that the very term 'religion' did not occur once in his work"-a hint to Rosenzweig, who claimed in New Thinking that the word "religion" does not appear in the Star (although it does). See Leo Strauss, "The Living Issues of German Post-War Philosophy," in Heinrich Meier, Leo Strauss and the Theologico-Political Problem, trans. Marcus Brainard (New York: Cambridge University Press, 2006), 128. On page 131 Rosenzweig is listed together with Gogarten. See also Leo Strauss, "Preface to Hobbes' politische Wissenschaft (1965)," in Strauss, Jewish Philosophy and the Crisis of Modernity, 453.
} 
note. In particular, as demonstrated above in Rosenzweig, it was the exaggerated negativity featuring the God-world relationship and the "Gnostic" devaluation of humanity, the world, and history that derives from it which was a bitter pill to swallow. ${ }^{71}$ Thus an important element of the Jewish readings of Rosenzweig vis-à-vis Karl Barth consists not only of the acknowledgment of their apparent similarities, but also of a strong impetus to expose and underscore their dissimilarities. For example, Max Grünewald, the rabbi of the Jewish community of Mannheim and a central figure in the German Jewry, maintains in a critical appraisal of Rosenzweig's thought that he, Rosenzweig, "is also concerned with at least part of the issues of dialectical theology. Like them, he strips the last egomaniacal [ selbstherrliche] earthly grandeur $[G r o ̈ \beta e]$ of its high-handedness ... what he thinks about progress and eternity, what he says about truth being created truth-that is related

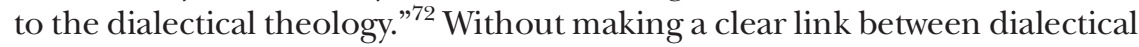
theology and Gnosticism, Grünewald recognizes that Rosenzweig opposes a position that could be easily attributed to both: "the statements about the hidden and revealed God, may be meant figuratively [uneigentlich] as a scaffold that can be dismantled after completion, [yet they still] run close to the edge of Gnosis. But with one sentence, Rosenzweig succeeds to rip open an abyss that separates him from it: 'revelation reaches only till the Creator'. Gnosis teaches exactly the opposite."73 Grünewald acknowledges that Rosenzweig deals with similar theological issues as do the thinkers of dialectical theology and that he also seems to commit to the notions of Deus absconditus and Deus revelatus. Yet at the crucial point Rosenzweig defies the Gnostic conclusions and resists their conceptual and religious pitfalls by attributing creation and revelation to the same God.

A more explicit attempt to minimize the acknowledged semblances between Rosenzweig and Barth is carried out by Else Freund, whose published dissertation Die Existenzphilosophie Franz Rosenzweigs (1933) was the first extensive study on Rosenzweig. In it she aims to reveal his debt to Schelling's positive works as well as to situate his New Thinking in the wider context of contemporary philosophical discourses. ${ }^{74}$ Freund admitted the essential role of revelation in Rosenzweig and Barth, yet she felt compelled to forestall overstating this point of comparison. Thus she specified that Barth's account of

\footnotetext{
${ }^{71}$ See Herskowitz, "Impossible Possibility?"

${ }^{72}$ See Rabbiner Dr. Max Grünewald, "Wege zu eine jüdischen Theologie," Frankfurter Israelitisches Gemeindeblatt 12, no. 1 (September 1933): 3-5.

73 Ibid., 4.

${ }^{74}$ Else Freund, Die Existenzphilosophie Franz Rosenzweig: Ein Beitrag zur Analyse seines Werkes: "Der Stern Der Erlösung" (Leipzig: Felix Meiner, 1933). A slightly revised edition of this work was published in Hebrew, translated by Jehoshua Amir (Tel Aviv: Schocken, 1972), and later in English as Else Rahel-Freund, Franz Rosenzweig's Philosophy of Existence: An Analysis of "The Star of Redemption", trans. Stephen L. Weinstein and Robert Israel, ed. Paul Mendes-Flohr (The Hague: Martinus Nijhoff, 1979). Reference and citation here are taken from the English edition with occasional amendments.
} 


\section{The Journal of Religion}

revelation is one in which God is completely dominant and active, while the human receiver is outright negligible in the face of the almighty. This framing, she affirms, is deeply at odds with Rosenzweig's understanding: "Rosenzweig's conception of revelation as relation between God and man is to be distinguished from all doctrines of revelation which devalue [entwerten] man as recipient of the revelation, such as the dialectical theology of Barth and Gogarten." 75 In contrast to their extreme prioritization of the divine over the fallen human, "in Rosenzweig's case, both poles, God and man, are upheld equally; both are needed precisely in their autonomy in order to make revelation possible." 76 Freund returns to this point in her discussion of the relations between the threefold coordinates of Creation, Revelation, and Redemption in the Star. What emerges from Rosenzweig's view, she avers, is that revelation is a relational event in which man is both active and passive. This view implies that "Man can generate God neither from feeling nor from knowledge-in accordance with the approach of idealistic theology. Nor is man a nought [Nichts] in the face of God, as taught by the dialectical theology of Barth and Gogarten."77 Unlike Barth's antihumanistic position that nullifies the human being, in Rosenzweig's view, "God may not surpass the human capacity for comprehension to such an extent that he ultimately becomes obscure and inaccessible. It must be possible to attest to God and therefore to preserve his independent, though passive, existence. Revelation can only occur to someone, not to a nought. In this way man's concealed objectivity protects not only God but man himself from annihilation in that which is facing him." ${ }^{78}$ Unlike Barth, Freund claims, Rosenzweig asserts that not only God, but also the human is a subject.

Also recognizing the comparability of the two thinkers while stressing the more critical moments of disagreements - and indicating Rosenzweig's ultimate theological superiority - is Alexander Altmann. As a young Orthodox rabbi and theologian who shared with Rosenzweig and Barth serious reservations regarding the liberal and historicist legacy, Altmann identified the appeal of dialectical theology as well as the challenge it presented to Judaism. His recurring engagement with what he considered the possible bearings dialectical theology had on Judaism finds its most elaborate expression in an essay entitled "Zur Auseinandersetzung mit der dialektischen Theologie" (1935), where he briefly comments on what he found to be the shared theological horizon of Rosenzweig and Barth. ${ }^{79}$ Discussing the anti-idealistic idea,

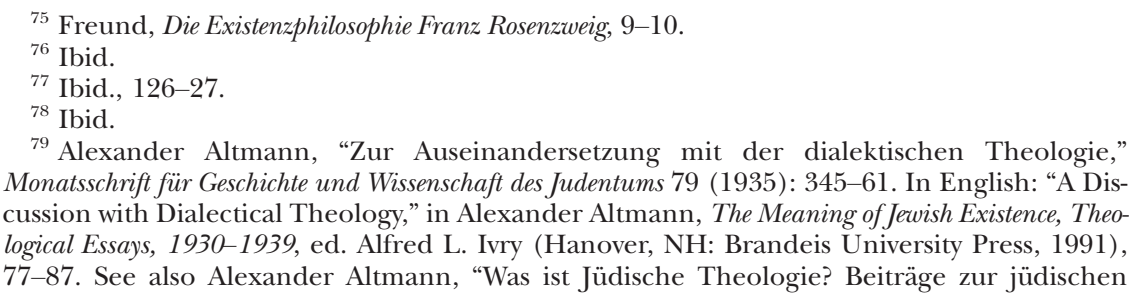


taken up by Barth, according to which God is not constructed by the human mind but is rather revealed in His actuality in the event of revelation, Altmann expounds that "the proximity of these thoughts to Franz Rosenzweig's rejection of idealism and the construction of an existential I-thou theology . . is obvious." Altmann is careful to claim only the "proximity" [die Nähe] of these views, for the differences, he posits, are crucially important: "for Rosenzweig's Jewish consciousness," Altmann explains, "idealism turns out to be not only inadequate as regards the reality of God, but false already as regards the world. The 'decision', which also has taken place in the Jewish realm, will therefore not be of the same kind as the 'decision' demanded and carried out by Barth. The Jewish 'decision' will not be able to turn its back on the world as can that of Barth." ${ }^{80}$ Despite their shared rejection of the idealistic attitude and their concern for a theocentric theology, Altmann disputes, the contradiction between the world and God animating Barth's scheme causes the existential "decision" of faith to implicitly mean the denial of the world's value. This step, insists Altmann, is one Rosenzweig, or any Jew for that matter, cannot take. ${ }^{81}$

The acknowledgment and reaction to the affiliation between Rosenzweig and Barth manifests the convoluted theological encounter between Judaism and Christianity in the early decades of the twentieth century. Through it the Jewish and Christian shared theological renouncement of liberalism and historicism of the nineteenth century comes to the fore, as does a similar path taken in response: the reconstitution of divine transcendence and the formulation of a theocentric theology. Yet the radical and wholesale manner in which dialectical theology and in particular Barthianism executed this task posed anew the fundamental challenge: how to uphold divine transcendence while simultaneously remaining attentive to the theological pitfalls - termed at the time Gnosticism or Marcionism - that an unbridgeable distancing between God and the world holds in store. Indeed, in a comparable manner to a major Christian response to Barth's radical theology that found its hyperbolic rift between

\footnotetext{
Neuorientierung," article series in Der Israelit 1933, republished in English as "What Is Jewish Theology?," in Altmann, The Meaning of Jewish Existence, 40-56; Alexander Altmann, "Zwischen Philosophie und Theologie: Drei Buchbesprechungen," Der Israelit, no. 14/15 (April 7, 1933): 1-2; Paul Mendes-Flohr, "Theologian before the Abyss," in Altmann, The Meaning of Jewish Existence, $\mathrm{xl}$.

${ }^{80}$ Altmann, "A Discussion with Dialectical Theology," 78.

${ }^{81}$ In a review written in Hebrew of Erich Przywara's Religionsphilosophie Katholischer Theologie (1926) and Analogia Entis (1932), Hugo Bergmann, the Czech-Israeli scholar and philosopher, points to some kinship between the Jesuit, one of the notable critics of Barth at the time, and Rosenzweig. See Hugo Bergmann, "Sefarim Philosophim Chadashim," Moznaim 5, no. 1 (1934): 85-88.
} 


\section{The Journal of Religion}

God and world uncomfortably Gnostic and as such at odds with the Christian message, in Jewish circles, Rosenzweig, whose biography and philosophy embodied the temptation and ultimate overcoming of Gnostic Barthianism, as well as others who identified the kinship between the Jewish and Christian thinkers, echoed this evaluation and rejection.

The Jewish reception of dialectical theology is no doubt a multifaceted moment in the area of twentieth century Christian-Jewish relations in general and Jewish thought in particular. The juxtaposition of Rosenzweig and Barth, which as we have seen has been repeatedly made in recent scholarship but in fact extends back to the interwar period, represents merely one chapter in a generally overlooked topic of scholarly inquiry. What is certain, however, is that the Jewish theological discourse did not ignore the great debate that occupied the Christian-theological world in Germany in the 1920s and 1930s over dialectical theology but rather participated in it from its own perspective. 